\title{
Youth sport coaches' role in facilitating positive youth development in Portuguese field hockey
}

Article in International Journal of Sport and Exercise Psychology • May 2016

DOI: 10.1080/1612197X.2016.1187655

CITATIONS

0

3 authors, including:

\section{Martin Camiré}

University of Ottawa

43 PUBLICATIONS 271 CITATIONS

SEE PROFILE
READS

41 


\section{International Journal of Sport and Exercise Psychology}

\section{Youth sport coaches' role in facilitating positive youth development in Portuguese field hockey}

\section{Fernando de Sousa Ferreira dos Santos, Martin Camiré \& Paulo Henrique da Fonte Campos}

To cite this article: Fernando de Sousa Ferreira dos Santos, Martin Camiré \& Paulo Henrique da Fonte Campos (2016): Youth sport coaches' role in facilitating positive youth development in Portuguese field hockey, International Journal of Sport and Exercise Psychology, DOI: 10.1080/1612197X.2016.1187655

To link to this article: http://dx.doi.org/10.1080/1612197X.2016.1187655

曲 Published online: 26 May 2016.

Submit your article to this journal $\asymp$

View related articles

View Crossmark data $\asymp$ 


\title{
Youth sport coaches' role in facilitating positive youth development in Portuguese field hockey
}

\author{
Fernando de Sousa Ferreira dos Santos ${ }^{\mathrm{a} *}$, Martin Camiré ${ }^{\mathrm{b}}$ and Paulo Henrique da Fonte Campos ${ }^{\mathrm{a}}$ \\ ${ }^{a}$ Portuguese Hockey Federation, Porto, Portugal; ${ }^{b}$ School of Human Kinetics, University of Ottawa, \\ Ottawa, Canada
}

(Received 23 November 2015; accepted 26 April 2016)

\begin{abstract}
Researchers have examined youth sport coaches' role in facilitating positive youth development (PYD). This past research demonstrates that when coaches use an intentional approach to development, they can play an important part in helping young people to reach adulthood with the necessary competencies to face the social challenges ahead. However, studies within the area of PYD through sport have predominantly emanated from Englishspeaking countries and there remains a need to better understand coaches' views on PYD within different countries' sport systems. The purpose of this study was to examine Portuguese coaches' perspectives on their role in facilitating PYD in youth field hockey. The participants were 11 youth field hockey coaches ( 2 females and 9 males) who coached athletes between 6 and 18 years of age. Findings showed how the coaches believed PYD could be fostered as they discussed several PYD-related concepts (e.g. life skills) they deemed were being developed in field hockey. However, creating enjoyable environments and talking about life skills with players were the only explicit initiatives discussed by the coaches with the intent of fostering PYD. Coach education was perceived by half the sample as an important learning situation to gain competencies to facilitate PYD, while the other half emphasised that coach education courses were lacking in material associated with this topic. Those who saw value in coach education presented a narrow view of PYD as being solely associated with the psychological aspects of coaching. Moving forward, coach education courses should first be designed to have coaches understand the full spectrum of the concept of PYD and be framed as suitable learning environments where coaches can learn how to foster PYD.
\end{abstract}

Keywords: positive youth development; youth coaches; field hockey; life skills

Increasing evidence supports the notion that sport participation can positively influence youth development, if the necessary conditions are in place (Fraser-Thomas, Côté, \& Deakin, 2005; Holt, 2016; Petitpas, Cornelius, Van Raalte, \& Jones, 2005). Positive youth development (PYD) represents an approach to research and programming whereby youth are viewed as resources to be developed (Lerner, Almerigi, Theokas, \& Lerner, 2005). The PYD approach fits within a positive psychology perspective (Seligman \& Csikszentmihályi, 2000) and emphasises individuals' strengths for them to become well-adjusted adults that thrive in all of life's endeavours. In recent decades, the paradigmatic shift from the deficit-reduction approach has gained ground in the sport community (Bowers et al., 2010; Vierimaa, Erickson, Côté, \& Gilbert, 2012).

\footnotetext{
*Corresponding author. Email: fernando.sfsantos@hotmail.com
} 
Sport represents an important setting in which to promote PYD as participation provides opportunities for young people to become responsible (Hellison, 2011) and learn the life skills (e.g. goal, setting, teamwork) needed to succeed in the different environments in which they live (Danish, Forneris, Hodge, \& Heke, 2004). The PYD perspective has had a visible presence in sport research for over a decade and it has been used to understand how youth can thrive within the systems of social relations that exist in sport (Agans, Vest Ettekal, Erickson, $\&$ Lerner, 2016). As the PYD perspective has been adopted by more and more researchers as a preferred theoretical lens, it has been used to explain a range of outcomes that can occur in sport, such as talent development, leadership development, and mental health (Holt, 2016). Despite its potential as a positive developmental context, sport can also lead to negative developmental outcomes for youth, based on how it is structured and overseen (Hodge \& Gucciardi, 2015; Rutten et al., 2011). For example, Fields, Collins, and Comstock (2010) discussed the many occurrences of violent behaviour that can occur in youth sport, while Bean, Fortier, Post, and Chima (2014) stated how organised youth sport can represent a stressor to young people and their families due to the high competitive expectations placed on athletes. The differences that often exist between preferred outcomes and actual experiences in sport have been well documented (e.g. Forneris, Camiré, \& Trudel, 2012). Thus, to achieve developmental experiences consistent with the principles of PYD, sport contexts must be structured to promote fun and be designed to facilitate youth development in an intentional manner (Merkel, 2013).

Within the sport psychology literature, frameworks have been developed to facilitate youth development in an intentional manner (Coakley, 2011). For instance, Hellison (2011) conceptualised the teaching personal and social responsibility model (TPSR), which has inspired interventions aimed at using after-school physical activities to develop responsibility in at-risk youth (Escartí, Gutiérrez, Pascual, \& Marín, 2010; Jung \& Wright, 2012; Martinek, Schilling, \& Hellison, 2006; Ruiz et al., 2006; Walsh, Ozaeta, \& Wright, 2010). Within TPSR, instructors facilitate youth's progression along the five levels of responsibility, with the goal of equipping youth with the skills needed for a successful transition to adulthood (Belando, Ferriz-Morell, \& Moreno-Murcia, 2012). Petitpas et al. (2005) developed their framework for planning youth sport programmes with the intent of deliberately fostering psychosocial development. Within this framework, coaches are seen as important external assets responsible for creating motivational climates and purposely structuring activities that help ensure youth's developmental needs are met. However, it is important to note that these and other frameworks (e.g. Gould \& Carson, 2008) that intentionally target PYD-related principles have generally not been adopted by mainstream sport programmes. Coakley (2016) discussed how this non-adoption of PYD-related principles is mainly due to the fact that the "changes required to implement a PYD approach generally challenge the institutional logic and the organizational identity that dominates and defines most competitive youth sport leagues, clubs, and teams today. This creates forms of resistance that are difficult to overcome" (p. 27). Thus, developmental frameworks created by researchers have yet to reach and influence the millions of youth who practice organised sport around the world.

Despite the organisational resistance identified, findings from empirical research conducted within mainstream sport programmes suggest that some coaches do prioritise PYD. (Camiré, Forneris, Trudel, \& Bernard, 2011; Trottier \& Robitaille, 2014) Camiré, Trudel, and Forneris (2014) interviewed 16 high school coaches from different sports and demonstrated how these coaches were genuinely open to learning and gaining competencies to foster PYD. Collins, Gould, Lauer, and Chung (2009) showed how the high school football coaches in their study were motivated to win but emphasised that their players' psychosocial development was the central element of their coaching philosophy. Within research, there has 
also been in recent years a growing interest in identifying the best approaches for coaches to use to facilitate PYD (Falcão, Bloom, \& Gilbert, 2012; Flett, Gould, Griffes, \& Lauer, 2013, 2012). For instance, Camiré et al. (2011) stressed the need for coaches to have well-defined coaching philosophies, to focus on developing meaningful relationships with athletes, and to have athletes deliberately practise life skills development and transfer. Turnnidge, Côté, and Hancock (2014) focused on the notion of skill transfer, distinguishing between the explicit (i.e. identifying the skills learned in sport and helping athletes recognise that these skills can be applied in other settings) and implicit approach (i.e. no intentional strategies to promote skill transfer). The researchers indicated how the explicit approach can positively influence skill transfer but that it has mainly been used by instructors working within sport-based PYD programmes such as TPSR (Hellison, 2011) and The First Tee (Weiss, Stuntz, Bhalla, Bolter, \& Price, 2013). The mentioned studies highlighted that the effectiveness of implicit approaches may be dependent on the quality of the coach-athlete relationship. Within mainstream sport programmes, coaches often employ little or no direct strategies to teach for transfer (e.g. Lacroix, Camiré, \& Trudel, 2008), but as Chinkov and Holt (2015) have discussed, the life skills learned within sport can nonetheless transfer implicitly and change the participants' lives in a significant manner.

Although past research has shown how many youth sport coaches acknowledge the importance of addressing PYD in their coaching (e.g. Gould, Chung, Smith, \& White, 2006), institutional-level changes are still required for PYD-related principles to be systematically integrated within youth sport programming. As Coakley stated: "PYD ultimately requires actions that engage and change the community. Such actions do not occur simply as a result of sport participation. They must be carefully planned and facilitated by those who manage and coach youth sports" (p. 30). One community-level change that must be further promoted to help coaches effectively foster PYD is the improvement of the delivery of coach education programmes (Conroy \& Coatsworth, 2006). Coach education, as a learning support, has the potential to provide "multiple opportunities to test and refine knowledge and skills, make coaching judgments that are meaningful within their particular situation, and understand the pragmatic constraints of coaching contexts" (Cushion, Armour, \& Jones, 2003, p. 225). MacDonald, Côté, and Deakin (2010) showed how athletes trained by coaches who had knowledge of PYD principles had higher levels of personal and social skills compared to athletes working with coaches who were not aware of PYD principles. Such evidence indicates that coach education should be playing a more prominent role in helping coaches to adopt coaching styles consistent with the PYD approach. In fact, recent coach education interventions have shown some level of success in sensitising coaches to the importance of facilitating PYD through sport (Falcão et al., 2012; Strachan, MacDonald, \& Côté, 2016).

Despite the fact that research in the area of PYD through sport has grown considerably in the last decade, it is currently dominated by researchers from English-speaking countries, as evidenced by the origin of the contributors in the second edition of the book Positive youth development through sport (Holt, 2016). There is a need to expand research more widely to better understand how PYD is framed and conceptualised in non-English-speaking countries. In Portugal, PYD through sport research remains a line of inquiry still in early development (Esperança, Regueiras, Brustad, \& Fonseca, 2013), making it important to conduct studies that attempt to comprehend the realities of the youth sport coach in this country. Therefore, the purpose of the present study was to examine Portuguese coaches' perspective on their role in facilitating PYD in elite youth field hockey. Three questions guide the study: (1) What are the coaches' perspectives on PYD within youth field hockey? (2) What strategies do coaches use to promote PYD in 
their players? (3) What do coaches believe is the role of coach education in helping them to facilitate PYD in field hockey?

\section{Method}

\section{Context}

Coaches were recruited from Portuguese field hockey clubs competing in the national league and other associated championships. According to Portuguese legislation, coaches must possess a coaching certificate to coach in organised youth sport, making coach education mandatory across all sports in the country (Euro Hockey, 2014). Coaches can acquire their coaching certificate in Portugal, or in another European country, by enrolling in coaching courses offered by sports federations. Universities, particularly graduate programmes in sports science, also play an important role because students can obtain their coaching certificate through an equivalence system. Although still relatively small, the number of young Portuguese athletes taking part in field hockey has seen consistent growth from 2012 to 2014. Currently, approximately 1838 athletes compete in championships organised by the Portuguese Hockey Federation, spread across 10 clubs around the country (Portuguese Hockey Federation, 2015). Given the relatively small number of field hockey participants in Portugal, coaches operate within a system where most people know each other, allowing for a constant exchange of information and proximity compared to bigger mass participation sports (e.g. soccer). In Portugal, the vast majority of sports are practised within clubs, with very few structures existing for sport within schools. Such a system is consistent with other European countries but differs from what is found in North America where school sport is much more prevalent (Pot \& Hilvoorde, 2013).

\section{Participants}

The participants were 11 youth field hockey coaches ( 2 females and 9 males) from Portugal who trained athletes from 6 to 18 years of age (see Table 1 for demographic information). Eight of the participants indicated having formerly played for the Portuguese national field hockey team.

Table 1. Coaches' demographic profile.

\begin{tabular}{|c|c|c|c|c|c|c|}
\hline Age & Gender & $\begin{array}{l}\text { Years coaching } \\
\text { experience }\end{array}$ & $\begin{array}{l}\text { Highest level } \\
\text { of education }\end{array}$ & $\begin{array}{l}\text { Coaching } \\
\text { certificate }\end{array}$ & $\begin{array}{l}\text { Experience } \\
\text { as a player }\end{array}$ & $\begin{array}{l}\text { Time spent with } \\
\text { players }\end{array}$ \\
\hline 33 & Female & 4 & $\begin{array}{c}\text { Bachelor Sports } \\
\text { Management }\end{array}$ & Yes & Yes & 2x/week/50 min* \\
\hline 36 & Male & 20 & Bachelor PES & Yes & Yes & 3x/week/90 min \\
\hline 56 & Male & 24 & Bachelor PES & Yes & Yes & $3 \mathrm{x} /$ week/90 min \\
\hline 59 & Male & 10 & Primary Education & Yes & Yes & $3 x /$ week $/ 60 \mathrm{~min}$ \\
\hline 30 & Male & 4 & $\begin{array}{l}\text { Bachelor Sports } \\
\text { Management }\end{array}$ & Yes & Yes & $3 x /$ week/90 min \\
\hline 37 & Male & 15 & Bachelor PES & Yes & No & $3 \mathrm{x} /$ week/90 min \\
\hline 34 & Female & 2 & High School Diploma & Yes & Yes & $3 \mathrm{x} /$ week $/ 120 \mathrm{~min}$ \\
\hline 37 & Male & 5 & High School Diploma & Yes & Yes & 3x/week/90 min \\
\hline 35 & Male & 10 & $\begin{array}{l}\text { Bachelor Graphics } \\
\text { Design }\end{array}$ & Yes & Yes & $2 \mathrm{x} /$ week/120 $\min$ \\
\hline 30 & Male & 7 & Bachelor Journalism & Yes & Yes & 2x/week/90 min \\
\hline 44 & Male & 5 & High School Diploma & Yes & Yes & 3x/week/90 min \\
\hline
\end{tabular}

Note: PES $=$ Physical Education and Sport.

*Each training session. 


\section{Procedure}

Prior to data collection, ethical clearance was received from the researchers' university ethics board and the Portuguese Hockey Federation. A purposeful sampling technique (Silverman, 2000) was employed to recruit youth field hockey coaches using the following criteria: (1) coached youth field hockey players in Portugal, (2) had obtained a coaching certificate, and (3) had at least one year of coaching experience. A technical director with the Portuguese Hockey Federation served as a key informant and provided a list of 20 coaches that met the study's inclusion criteria. A total of 13 coaches were successfully reached by the researchers and subsequently debriefed on the study's objectives. During the debrief, PYD was defined to the potential participants as "a broad approach that intends to foster values as well as personal and social skills so young people can reach adulthood well prepared" (Lerner et al., 2005). The decision was taken to offer a definition of PYD to the potential participants for them to understand the topic under investigation, given that PYD is not yet a mainstream concept in Portugal. Of the 13 coaches contacted, 1 declined to take part and another did not fulfil the criteria and thus, 11 coaches participated in this study. The first author proceeded to schedule interview times with the participants, according to their availability. Prior to undertaking the interviewing process, the coaches were asked to sign a consent form that clearly explained their rights to anonymity and confidentiality. The interviews were audio recorded and lasted between 17 and $25 \min (M=19)$.

\section{Interview guide}

The interview guide was created based on guides employed in past qualitative studies that examined coaches' role in facilitating PYD (Camiré, Trudel, \& Forneris, 2012; Camiré et al., 2014). Prior to creating the final version of the interview guide, two pilot interviews were conducted, with the interview guide being subjected to minor changes. The interview guide was divided into two parts. First, questions centred on gathering demographic data from the participants. Second, questions were intended to document coaches' perspectives on PYD (see Appendix for the interview guide).

\section{Data analysis}

The interviews were transcribed verbatim. The transcripts were read multiple times by the authors and subsequently downloaded to the qualitative data analysis software NVivo10, which was used to organise the data. A question-focused thematic analysis was conducted (Silverman, 2000). The analysis started by segmenting the participants' responses into meaning units, which were then compiled into low- and high-order themes (e.g. family orientation in field hockey). The analysis was framed as a question-focused analysis, given that the themes developed were subsequently arranged to fit within one of the three main research questions, which served as overarching categories. The research team constantly reviewed the categories, with the first author maintaining an analysis journal to document and reflect on all of the changes made during the analytical process. Within the overarching categories aligned with each research question, a negative case analysis was conducted to ensure that diverging perspectives were analysed and proportionally reported in the paper (e.g. coaches' divergent views on the role of coach education). Once the organisation of the data was deemed appropriate to answer the research questions, the writing of the report was undertaken. Given that the interviews with the participants were conducted in Portuguese, the quotes used in this paper were translated to English by the first author. To help ensure that the essence of each quote was maintained, the services of a bilingual person with the necessary certifications were solicited to corroborate the first author's translation efforts. 
To ensure quality standards, member checking was employed by emailing each participant his/her transcript. Coaches were instructed that changes to their transcript should be returned to the researchers within one week. Four coaches acknowledged the email and none asked for modifications to be made. The absence of a reply from the other coaches was deemed as a confirmation that their transcript was accurate. Furthermore, an expert in qualitative research was solicited to participate in the study and assisted the researchers during data analysis and manuscript writing.

\section{Results}

\section{Field hockey's potential in promoting PYD}

Several coaches believed that field hockey has inherent features that enable the promotion of PYD. Field hockey teams are comprised of a fairly small number of individuals which, in the perspective of the coaches, leads to a strong sense of family subculture. On this notion, two participants stated: "Hockey as a sport is spectacular. In Portugal, let's speak about our country, it's a family sport where everyone knows each other and that's an asset for young people because they feel at home and they don't feel discriminated" (Coach 1) and "We say that we're more than a team, we're a family because we're all together, we're close" (Coach 10). Because of this sense of family subculture, one coach believed that field hockey constituted a context where athlete development needed to be prioritised: "My major concern as a youth coach is to promote personal and social development, make players feel happy at the club by creating a family. The most important thing for us is to teach them values" (Coach 4). Features related to field hockey's equipment, structure, and rules were also discussed by coaches as providing solid grounds for the fostering of PYD. One coach said:

Hockey is played with a small ball, very hard and with a stick that now is made with fiber [composite material], so it's a weapon. This implies that there has to be great self-control and discipline from participants. Everything that's violence, dangerous play, active or passive, in hockey it's penalised. (Coach 6)

The coaches provided several examples of life skills they believed were developed through field hockey, thereby helping foster PYD in all aspects of their athletes' lives. Some coaches discussed how respect can be learnt through field hockey: "I think respect for their elders due to the fact that in sport, we must follow rules, because if not, there's no game, no sport" (Coach 10). Commitment and a strong work ethic were also deemed important attributes that can be developed through field hockey that are highly applicable in other areas of life: "I think the ability to commit is needed for everything, in their personal lives and during physical effort" (Coach 4) and "If they understand that to be better at hockey, they have to work [hard], in school, it's the same thing" (Coach 11). Teamwork was another skill coaches' believed was developed through field hockey, in line with its strong sense of family subculture. On this notion, two coaches stated: "The ability that can come from collective sport is to know how to work as a group, teamwork" (Coach 1) and "Competencies that are important in collective terms: solidarity, friendship, togetherness, and feeling part of a group are very important. Understanding the importance we can have together, not acting alone" (Coach 7). For coaches working within smaller clubs, leadership was viewed as a particularly important skill to develop in athletes. One coach explained how given his club's limited resources, he has to prepare some of his athletes to eventually become coaches within the club:

We are a small club with no money, no sponsors, no nothing. We survive through our initiatives. We try to give more value to youngsters that are available to be volunteers. We have several examples of 
kids who are part of the senior team, still sixteen, seventeen years old, that start to coach or to help the field hockey coach. (Coach 9)

Although the coaches believed that PYD can be facilitated in Portuguese field hockey, a few stated how they felt the sport was equivalent to other sports in terms of its potential to promote PYD. For several coaches, all sports were deemed useful training grounds to teach important life lessons that are conducive to PYD. On this notion, two coaches stated: "I think hockey's place is the same as just any other sport. When we speak about the importance of sport in preparing athletes for life, I think it's common" (Coach 8) and "Foremost, it is important to include young people in mainstream sport; positive youth development can be achieved in the same way in any sport activity, not just in field hockey" (Coach 2). Despite the fact that field hockey was deemed conducive to the development of many life skills, some coaches discussed how within field hockey clubs in Portugal, PYD is often given lip service but few initiatives are actually in place to promote development in a deliberate manner. On this notion, one coach stated: "In terms of coaches and approaches, I think we're a little bit behind in this aspect" (Coach 11). Another coach discussed how winning supersedes other concerns and limits the efforts directed at PYD: "They [clubs] want to win at all cost and when things do not go their way, they get aggressive" (Coach 3). Finally, one coach argued that in Portuguese field hockey, PYD is important but when it really comes down to it: "Unfortunately, the major concern is to compete, to win" (Coach 1).

\section{Coaching strategies to promote PYD}

Many of the coaches believed that PYD outcomes can be derived from participation in field hockey by using an explicit approach. One coach confidently answered that at his club, facilitating PYD is a major concern: "Positive youth development is definitely a priority as we try to develop these assets in our young players" (Coach 4). Another coach stated how at his club, many children come from disadvantaged areas and thus, PYD is definitely a high-priority objective:

We work directly this aspect, because we deal with children that have lots of difficulties in their family life, in school, and socially. Positive youth development, as I see it, is to use sport, in this case field hockey, so they can learn new horizons. (Coach 9)

However, when asked to describe in concrete manners how they work explicitly to facilitate PYD, the coaches were not able to provide many examples of deliberate initiatives. One coach, when asked to describe his PYD-related coaching strategies, was completely honest about the lack of intentionality in his approach: "I try to promote positive youth development in my coaching practice. However, I cannot name specific strategies or activities that I do to achieve this goal" (Coach 7). Some coaches made efforts to describe some strategies that they use to try to set the stage for PYD to occur. For instance, two coaches stated how they try to make field hockey a positive environment in which players can have fun and enjoy themselves: "I like to make them look at me as a friend that's there to help, to have fun with them" (Coach 10) and "After in the locker room, I joke with them. Training cannot be always the most important thing" (Coach 2). Beyond making efforts to create enjoyable environments, very few strategies were mentioned by the coaches that could be linked to aspect related to PYD. One coach provided an example of how he verbally challenges his athletes to set high standards for themselves in terms of what they can accomplish: "Speaking. Sometimes we're having lunch or dinner and they say 'I can't do it' and I ask 'Why? Have you tried?' Then, I wait and be like 'See, you can do it'” 
(Coach 3). For another coach, he conceptualised addressing PYD as explaining to his athletes that winning is not the only outcome to be pursued in sport: "I tell them, I always do, that more important than winning is to know how to behave. It's an image that we must show" (Coach 8).

\section{The role of coach education}

The coaches all discussed how they believe coach education is an important learning situation in the development of youth sport coaches. One coach explained how coach education provides a solid base in the fundamentals of sports coaching: "The courses are important so we understand the sport. It's not just running [around]" (Coach 5). Another coach added that coach education courses bring people together, making it possible for coaches to expand their networks and compare their ideas with others: "Coach education courses are useful because coaches can obtain knowledge and listen to different perspectives, which is very important" (Coach 3). Despite reaching a consensus on the worth of coach education, the coaches in our sample were divided in their belief of PYD being addressed or not in coach education and were at odds on the type of material they were exposed to. Half of the coaches believed that the coach education courses they took touched on what they considered to be the psychological features of coaching, which they associated with PYD. For example, one coach mentioned that coach education courses helped him to improve in the psychological aspects of coaching young athletes: "It's more about managing resources, the psychological issues, the way we teach so we can evolve" (Coach 5). Another coach, who had taken part in many coach education courses, stated that the psychological aspects of coaching were regularly covered in the material he was exposed to: "In all the coach education courses I have attended, we spoke about psychological skills and their importance. These issues are always included in the curriculum" (Coach 8).

The other half of coaches in our sample indicated that the coaching courses they took part in did not discuss material related to PYD. One coach explained how according to him, coach education courses do not touch the psychological side of sport: "A lot of times, the coaching courses focus mainly of the technical aspects related to hockey. Psychology passes by. I think the part associated with young people, in my perspective, does not have significant valorisation" (Coach 11). Another coach referred specifically to the concept of PYD, mentioning how coach education courses do not expose coaches to specific strategies on how to teach important life skills through sport: "Positive youth development is not valued in coach education courses. Most courses focused only on the technical aspects of the game and lacked in material that can help coaches teach athletes how to respect rules and learn life skills" (Coach 6). Given the lack of perceived PYD-related content in coach education, some coaches explained how they must be resourceful and take ownership of their own learning outside of coaching courses in order to improve their abilities: "It's important to search. Many coaches do not search, there has to be a will. I think it's the most important part, you have to search and always try to be better" (Coach 12). Another coach expressed a similar sentiment, adding the importance of testing out new approaches in order to meet the evolving needs of athletes: "I think besides what we learn in coach education courses, it is important to search and reflect continuously on new approaches to youth sport. We have to search so we can confront our difficulties and improve as youth coaches" (Coach 8).

\section{Discussion}

The purpose of this study was to examine Portuguese coaches' perspectives on their role in facilitating PYD in elite youth field hockey. Findings showed how coaches generally believed that field hockey in Portugal represented a context with inherent features that were conducive to 
PYD. The relatively small number of members within clubs was believed to foster a family-orientated culture that facilitated the satisfaction of athletes' developmental needs. Such findings are consistent with past research indicating how sport can serve as an appropriate context conducive to PYD (Hellison, 2011; Holt, Tink, Mandigo, \& Fox, 2008; Walsh et al., 2010). Moreover, the coaches in the present study discussed several life skills they believe can be gained from participation in field hockey and such findings support past research on coaches' perspectives of PYD in sport (Gould et al., 2006). Nonetheless, future studies should be conducted to examine if, as discussed by our participants, particular sports have inherent features that lead to developmental experiences that differ from other sports.

Despite holding high regards for field hockey as a developmental context, few coaches in our sample were able to articulate clear and deliberate strategies they used to facilitate their athletes' development. Thus, we found very little evidence of specific strategies in place to promote PYD, other than creating pleasurable environments (Ward \& Parker, 2013; Wright \& Li, 2009) and talking about some life skills (Barker \& Forneris, 2012; Escartí et al., 2012; Ward, Parker, Henschel-Pellett, \& Perez, 2012). Although promoting fun and a sense of family are important elements of an effective coaching philosophy, they by themselves are not sufficient to qualify as an explicit approach to PYD. Based on past literature (Chinkov \& Holt, 2015; Turnnidge et al., 2014), it appears that the coaches in our sample worked to create appropriate "PYD environments", suggesting that they endorsed more of an implicit approach to PYD. Researchers (e.g. Petitpas et al., 2005) have advocated that coaches should adopt an explicit approach to PYD to increase the likelihood of sport being a positive developmental experience for young athletes. However, to date, there is little solid empirical evidence in the literature indicating that the explicit approach should categorically be favoured over the implicit approach. Some studies are emerging in this area (e.g. Bean \& Forneris, 2016) but as Camiré and Kendellen (2016) have stated, more research is needed to determine precisely if there is actual added "developmental" value to coaches favouring an explicit approach over an implicit approach to PYD in the context of sport.

The difficulties coaches face in articulating developmental strategies have been reported in previous studies, both within school and community sport (Camiré, Trudel, \& Bernard, 2013; McCallister, Blinde, \& Weiss, 2000). In the present study, it is essential to consider that coaches' more implicit approach to PYD may just be a reflection of their lack of motivation and resources to adopt a more explicit approach to PYD. As some of our participants alluded to, the pursuit of victory remains the major concern within elite youth field hockey in Portugal. Moving forward, it appears that additional work is needed to convince coaches to move beyond the simplistic conceptualisation that winning and development are inherently incompatible (Gould, Collins, Lauer, \& Chung, 2007; Strachan, Côté, \& Deakin, 2011). Camiré (2015) discussed how youth sport can be reconciled as an activity where competition and PYD are inclusive pursuits on the journey towards performance in sport and performance in life. Thus, within a PYD perspective, competition must be viewed as a collaborative process of striving together for excellence, whereby our opponents must offer their best in order for us to reach our best. Within such a frame of reference, winning and development can be viewed as two equally important and carefully integrated endeavours within the youth sport coaching process. Additional research is needed to more precisely determine the type of synergies that are created when coaches target competition and PYD concurrently, thereby leading to a better understanding of if/how the explicit approach promotes performance in both sport and life.

Perhaps one reason why, as researchers, we continue to find empirical evidence of youth sport coaches primarily using an implicit approach to PYD (i.e. not including explicit PYD strategies in their coaching) is that "mainstream coach education programs lack content that is relevant to positive youth development, instead maintaining a focus on technical and tactical skills" (Vella, Oades, \& Crowe, 2013, p. 526). Although recent coach education interventions designed to promote an 
explicit approach to PYD have been shown to enhance coaches' personal growth (Falcão et al., 2012; Strachan et al., 2016), in the current study, the coaches were divided in terms of the perceived relevance of their coach education experiences in preparing them to foster PYD. Some coaches found utility in the content included in their coaching courses while others discussed how PYDrelated material was completely lacking. Despite providing a definition of PYD prior to interviewing, those who saw value in coach education presented a narrow view of PYD as being solely associated with the psychological aspects of coaching. Moving forward, coach education courses aimed for youth sport coaches should be designed to have coaches understand the concept of PYD (e.g. explain the difference between the implicit and explicit approach) and be framed as learning environments where practical strategies on how to foster PYD are presented. Although coach education represents a learning situation in which coaches can develop competencies and acquire strategies (Cushion et al., 2003; Malete \& Feltz, 2000), relevant content must be presented if coaches are to understand what PYD is (Camiré et al., 2014). Recently, in Portugal, some coach educators have started to embrace PYD-related content as worthwhile material to include in coaching courses. For example, the Portuguese Hockey Federation (2015) has just created a learning module entitled "Positive Youth Development" as a pilot training programme within their project "Positive Youth Development in the Coach Education Process of Youth Coaches". As discussed by Cronin and Armour (2015), such approaches to coach education can help restructure the discourse of elite youth sport more towards "youth performance coaching as a caring act, which aspires to educate young people through a commitment to the development of corporeal excellence" (p.11). Such efforts represent necessary and timely steps to address the organisational resistance that exists in embracing PYD in competitive youth sport (Coakley, 2016). Future research will need to include evaluations of these new PYD coach education schemes, such as the Portuguese Hockey Federation's "Positive Youth Development" pilot training programme, to measure their impact on coaching efficacy, coaching behaviours, and athlete outcomes. Additionally, in future studies, closer attention should be paid to demographic variables (e.g. education level, years of coaching experience) to ascertain if/how they influence coaches' (a) use of the implicit or explicit approach to PYD and (b) perspectives on the value of integrating PYD-related principles within coach education.

\section{Limitations}

It is important to understand that the current study was conducted in a sport context presenting particular features and as such, readers should exercise caution not to make inferences to other sports contexts with different features. Coaches in elite youth clubs have particular mandates and this is especially true in Portuguese field hockey where coaches have pressures to perform and to focus on competition, both factors that limit the extrapolation of the results to other sport settings. The participants' perspectives on coach education must also be seen as contextspecific given that in Portugal, coach education courses are mandatory, which is not the case in many countries. Another limitation is the small representation of female coaches within our sample and as such, future research efforts need to recruit more female coaches to better understand their views on PYD in sport and coach education. Finally, we acknowledge that some interviews were rather concise and further probing could have led to a more detailed understanding of some of the concepts discussed by the coaches.

\section{Conclusion}

Our findings suggest that coaches do value PYD as a key element of youth field hockey as they identified several life skills deemed to be developed through participation. However, the coaches 
provided few concrete strategies they used to deliberately promote PYD, a finding consistent with past research in this area (Lacroix et al., 2008; McCallister et al., 2000). Such findings suggest that the coaches did not adopt an explicit approach to PYD but rather used an implicit approach based on creating a good environment (e.g. promoting pleasure) where youth could gain some PYD outcomes. The field hockey coaches in the present study had diverging perspectives on the content included in coach education courses. Given that coach education is mandatory for coaches in Portugal, there is an opportunity in this country to expose all coaches to critical PYD concepts and related strategies that can be implemented to optimise sport as a developmental context.

\section{Funding}

This study was conducted with the support of the Portuguese Hockey Federation.

\section{References}

Agans, J. P., Vest Ettekal, A., Erickson, K., \& Lerner, R. M. (2016). Positive youth development through sport: A relational developmental systems approach. In N. L. Holt (Ed.), Positive youth development through sport (2nd ed., pp. 34-44). London: Routledge.

Barker, B., \& Forneris, T. (2012). Reflections on the implementation of TPSR programming with at-riskyouth in the city of Ottawa, Canada. Agora para la EF y el Deporte, 14(1), 78-93.

Bean, C., \& Forneris, T. (2016). Examining the importance of intentionally structuring the youth sport context to facilitate positive youth development. Journal of Applied Sport Psychology. Advance online publication. doi:10.1080/10413200.2016.1164764

Bean, C., Fortier, M., Post, C., \& Chima, K. (2014). Understanding how organized youth sport may be harming individual players within the family unit: A literature review. International Journal of Environmental Research and Public Health, 11, 10226-10268. doi:10.3390/ijerph111010226

Belando, N., Ferriz-Morell, R., \& Moreno-Murcia, J. A. (2012). Propuesta de un modelo para la mejora personal y social a través de la promoción de la responsabilidad en la actividad físico-deportiva [Proposal of a model for personal and social improvement through the promotion of responsibility for physical and sporting activity]. Revista Internacional de Ciencias del Deporte, 29, 202-222. doi:10.5232/ricyde2012. 02902

Bowers, E. P., Li, Y., Kiely, M. K., Brittian, A., Lerner, J. V., \& Lerner, R. M. (2010). The five Cs model of positive youth development: A longitudinal analysis of confirmatory factor structure and measurement invariance. Journal of Youth Adolescence, 39, 720-835. doi:10.1007/s10964-014-0095-x

Camiré, M. (2015). Reconciling competition and positive youth development in sport. STAPS, 109, 25-39. doi:10.3917/sta.109.0025

Camiré, M., \& Kendellen, K. (2016). Coaching for positive youth development in high school sport. In N. L. Holt (Ed.), Positive youth development through sport (2nd ed., pp. 126-136). London: Routledge.

Camiré, M., Forneris, T., Trudel, P., \& Bernard, D. (2011). Strategies for helping coaches facilitate positive youth development through sport. Journal of Sport Psychology in Action, 2, 92-99. doi:10.1080/ 21520704.2011.584246

Camiré, M., Trudel, P., \& Bernard, D. (2013). A case study of a high school sport program designed to teach athletes life skills and values. The Sport Psychologist, 27, 188-200.

Camiré, M., Trudel, P., \& Forneris, T. (2012). Coaching and transferring life skills: Philosophies and strategies used by model high school coaches. The Sport Psychologist, 26, 243-260.

Camiré, M., Trudel, P., \& Forneris, T. (2014). Examining how model youth sport coaches learn to facilitate positive youth development. Physical Education and Sport Pedagogy, 19, 1-17. doi:10.1080/17408989. 2012.726975

Chinkov, A., \& Holt, N. (2015). Implicit transfer of life skills through participation in Brazilian jiu-jitsu. Journal of Applied Sport Psychology. Advance online publication. doi:10.1080/10413200.2015. 1086447

Coakley, J. (2011). Youth sports: What counts as “youth development?” Journal of Sport \& Social Issues, 35, 306-324. doi:10.1177/0193723511417311

Coakley, J. (2016). Positive youth development through sport: Myths, beliefs, and realities. In N. L. Holt (Ed.), Positive youth development through sport (2nd ed., pp. 21-33). London: Routledge. 
Collins, K., Gould, D., Lauer, L., \& Chung, Y. (2009). Coaching life skills through football: Philosophical beliefs of outstanding high school football coaches. International Journal of Coaching Science, 3(1), 29-54. doi:10.1080/10413200601113786

Conroy, D., \& Coatsworth, D. (2006). Coach training as a strategy for promoting youth social development. The Sport Psychologist, 20, 128-144.

Cronin, C., \& Armour, K. (2015). 'Being' in the coaching world: New insights on youth performance coaching from an interpretative phenomenological approach. Sport, Education and Society, 20(8), 1-13. doi:10.1080/13573322.2015.1108912

Cushion, C., Armour, K., \& Jones, R. (2003). Coach education and continuing professional development: Experience and learning to coach. Quest, 55, 215-230. doi:10.1080/00336297.2003.10491800

Danish, S., Forneris, T., Hodge, K., \& Heke, I. (2004). Enhancing youth development through sport. World Leisure, 46(3), 38-49.

Escartí, A., Gutiérrez, M., Pascual, C., \& Marín, D. (2010). Application of Hellison's teaching personal and social responsibility model in physical education to improve self-efficacy for adolescents at risk of dropping-out of school. The Spanish Journal of Psychology, 13, 667-676.

Escartí, A., Pascual, C., Gutiérrez, M., Marín, D., Martínez, M., \& Tarín, S. (2012). Applying the teaching personal and social responsibility model (TPSR) in Spanish schools context: Lesson learned. Ágora para la EF y el Deporte, 14, 178-196.

Esperança, J., Regueiras, L., Brustad, R., \& Fonseca, A. (2013). Um olhar sobre o desenvolvimento positivo dos jovens através do desporto [A look at positive youth development through sport]. Revista de Psicologia del Deporte, 22, 481-487.

Euro Hockey. (2014). EHF/FIH academy level 1 coaching. Retrieved from http://www.eurohockey.org/ education/ehffih-academy-level-1-coaching-course-held-komotini-greece/

Falcão, W., Bloom, G., \& Gilbert, W. (2012). Coaches' perceptions of a coach training program designed to promote youth developmental outcomes. Journal of Applied Sport Psychology, 24, 429-444. doi:10. 1080/10413200.2012.692452

Fields, S., Collins, C., \& Comstock, R. (2010). Violence in youth sports: Hazing, brawling and foul play. British Journal of Sports Medicine, 44, 32-37. doi:10.1136/bjsm.2009.068320

Flett, M., Gould, D., Griffes, K., \& Lauer, L. (2012). The views of more versus less experienced coaches in underserved communities. International Journal of Coaching Science, 6(1), 3-26.

Flett, M., Gould, D., Griffes, K., \& Lauer, L. (2013). Tough love for underserved youth: A comparison of more and less effective coaching. The Sport Psychologist, 27, 325-337.

Forneris, T., Camiré, M., \& Trudel, P. (2012). The development of life skills and values in high school sport: Is there a gap between stakeholder's expectations and perceived experiences? International Journal of Sport and Exercise Psychology, 10(1), 9-23. doi:10.1080/1612197X.2012.645128

Fraser-Thomas, J., Côté, J., \& Deakin, J. (2005). Youth sport programs: An avenue to foster positive youth development. Physical Education and Sport Pedagogy, 10(1), 19-40. doi:10.1080/ 1740898042000334890

Gould, D., \& Carson, S. (2008). Life skills development through sport:Current status and future directions. International Review of Sport \& Exercise Psychology, 1(1), 21-58.

Gould, D., Chung, Y., Smith, P., \& White, J. (2006). Future directions in coaching life skills: Understanding high school coaches' views and needs. Athletic Insight, 8(3), 28-38.

Gould, D., Collins, K., Lauer, L., \& Chung, Y. (2007). Coaching life skills through football:A study of award winning high school coaches. Journal of Applied Sport Psychology, (19), 16-37.

Hellison, D. (2011). Teaching personal and social responsibility through physical activity (3rd ed.). Champaign, IL: Human Kinetics.

Hodge, K., \& Gucciardi, D. (2015). Antisocial and prosocial behavior in sport: The role of motivational climate, basic psychological needs, and moral disengagement. Journal of Sport and Exercise Psychology, 37, 257-273.

Holt, N. (2016). Positive youth development through sport (2nd ed.). London: Routledge.

Holt, N., Tink, L., Mandigo, J., \& Fox, K. (2008). Do youth learn life skills through their involvement in high school sport? A case study. Canadian Journal of Education, 31, 281-304.

Jung, J., \& Wright, P. (2012). Application of Helisson's responsibility model in South Korea: A multiple case study of 'at-risk' middle school students in physical education. Agora para la EF y el Deporte, 14, 140-160.

Lacroix, C., Camiré, M., \& Trudel, P. (2008). High school coaches' characteristics and their perspectives on the purpose of school sport participation. International Journal of Coaching Science, 2(2), 23-42.

Lerner, R., Almerigi, J., Theokas, C., \& Lerner, J. (2005). Positive youth development: A view of the issues. Journal of Early Adolescence, 25(1), 10-16. 
MacDonald, D., Côté, J., \& Deakin, J. (2010). The impact of informal coach training on the personal development of youth sport athletes. International Journal of Sports Science \& Coaching, 5, 363372.

Malete, L., \& Feltz, D. (2000). The effect of a coaching education program on coaching efficacy. The Sport Psychologist, 14, 410-417.

Martinek, T., Schilling, T., \& Hellison, D. (2006). The development of compassionate and caring leadership among adolescents. Physical Education and Sport Pedagogy, 11, 141-157. doi:10.1080/ 17408980600708346

McCallister, S., Blinde, E., \& Weiss, W. (2000). Teaching values and implementing philosophies: Dilemmas of the youth sport coach. Physical Educator, 57, 35-45.

Merkel, D. (2013). Youth sport: Positive and negative impact on young athletes. Journal of Sports Medicine, 13, 151-160. doi:10.2147/OAJSM.S33556

Petitpas, A., Cornelius, A., Van Raalte, J., \& Jones, T. (2005). A framework for planning youth sport programs that foster psychosocial development. The Sport Psychologist, 19, 63-80.

Portuguese Hockey Federation. (2015). Project "positive youth development in the coach education process of youth coaches". Retrieved from http://www.fphoquei.pt/blog/2015/11/projeto-o-desenvolvimentopositivo-na-formacao-de-treinadores-de-hoquei

Pot, N., \& Hilvoorde, I. (2013). Generalizing the effects of school sports: comparing the cultural contexts of school sports in the Netherlands and the USA. Sport in Society: Cultures, Commerce, Media, Politics, 16 (9), 1164-1175. doi:10.1080/17430437.2013.790894

Ruiz, L. M., Rodríguez, P., Martinek, T., Schilling, T., Durán, L. J., \& Jiménez, P. (2006). El Proyecto Esfuerzo: un modelo para el desarrollo de la responsabilidad personal y social a través del deporte [Project Effort. A model for the development of social and personal responsibility through sport]. Revista de Educación, 341, 933-958.

Rutten, E., Schuengel, C., Dirks, E., Stams, G., Biesta, G., \& Hoeksma, J. (2011). Predictors of antisocial and prosocial behavior in an adolescent sports context. Social Development, 20, 294-315.

Seligman, M., \& Csikszentmihályi, M. (2000). Positive psychology. An introduction. American Psychologist, 55, 5-14. doi:10.1037/0003-066X.55.1.5

Silverman, D. (2000). Doing qualitative research: A practical handbook. London: Sage.

Strachan, L., Côté, J., \& Deakin, J. (2011). A new view: Exploring positive youth development in elite sport contexts. Qualitative Research in Sport, Exercise and Health, 3(1), 9-32. doi:10.1080/19398441.2010. 541483

Strachan, L., MacDonald, J., \& Côté, J. (2016). Project SCORE! Coaches' perceptions of an online tool to promote positive youth development in sport. International Journal of Sports Science and Coaching, 11, $108-115$.

Trottier, C., \& Robitaille, S. (2014). Fostering life skills development in high school and community sport: A comparative analysis of the coach's role. The Sport Psychologist, 28, 10-21. doi:10.1123/tsp.2012-0094

Turnnidge, J., Côté, J., \& Hancock, D. (2014). Positive youth development from sport to life: Explicit or implicit transfer? Quest, 66, 203-217. doi:10.1080/00336297.2013.867275

Vella, S. A., Oades, L. G., \& Crowe, T. P. (2013). A pilot test of transformational leadership training for sports coaches: Impact on the developmental experiences of adolescent athletes. International Journal of Sports Science \& Coaching, 8, 513-530.

Vierimaa, M., Erickson, K., Côté, J., \& Gilbert, W. (2012). Positive youth development: A measurement framework for sport. International Journal of Sports Science \& Coaching, 7, 601-614. doi:10.1260/17479541.7.3.601

Walsh, D., Ozaeta, J., \& Wright, P. (2010). Transference of responsibility model goals to the school environment: Exploring the impact of a coaching club program. Physical Education and Sport Pedagogy, 15, $15-28$.

Ward, S., \& Parker, M. (2013). The voice of youth: Atmosphere in positive youth development program. Physical Education and Sport Pedagogy, 18, 534-548. doi:10.1080/17408989.2012.726974

Ward, S., Parker, M., Henschel-Pellett, H., \& Perez, M. (2012). Forecasting the storm: Student perspectives throughout a teaching personal and social responsibility (TPSR)-based positive youth development program. Ágora para la EF y el Deporte, 14, 230-247.

Weiss, M. R., Stuntz, C. P., Bhalla, J. A., Bolter, N. D., \& Price, M. S. (2013). 'More than a game': Impact of The First Tee life skills programme on positive youth development: Project introduction and year 1 findings. Qualitative Research in Sport, Exercise, and Health, 5, 214-244.

Wright, P. M., \& Li, W. (2009). Exploring the relevance of positive youth development in urban physical education. Physical Education and Sport Pedagogy, 14, 241-251. doi:10.1080/17408980801974978 


\section{Appendix: Coach interview guide}

Preamble:

- Explain study purpose

- Remind participants of their rights to confidentiality and anonymity

- Sign consent form

- Do you have any questions before we start?

(1) Demographic questions:
(a) Age
(b) Years of coaching experience
(c) Coach education status
(d) Highest level of education
(e) Time spent with players per week
(f) Players' age
(g) Highest level of experience as a player

(2) Perspective on PYD:
(a) Can you describe how you conceptualize PYD?
(b) What life skills do you believe youth learn from sport participation?
(c) What importance do you give to PYD in your coaching practice?
(d) How do you believe field hockey can promote PYD?
(e) What strategies do you use to promote PYD?
(f) What's your perspective on the work being done in Portuguese field hockey towards PYD?
(g) How do you believe that coach education contributes to your work towards PYD? 